\title{
THE IMPLEMENTATION OF THE PEDAGOGICAL CONDITIONS \\ AT THE REPRODUCTIVE AND ACTIVE STAGE OF TRAINING OF FUTURE DIPLOMATS IN INTERNATIONAL POLITICAL ECONOMY
}

\author{
РЕАЛІЗАЦІЯ ПЕДАГОГІЧНИХ УМОВ \\ НА РЕПРОДУКТИВНО-ДІЯЛЬНІСНОМУ ЕТАПІ ПІДГОТОВКИ \\ МАЙБУТНІХ ДИПЛОМАТІВ ІЗ МІЖНАРОДНИХ ЕКОНОМІЧНИХ ВІДНОСИН
}

\begin{abstract}
The article presents materials of a formative experiment of scientific research on the reproductive-activity stage. The model for the formation of professional and diplomatic communication of future specialists in international economic relations is aimed at the formation of the studied construct among students who are studying at the second educational level "Master". The forms and methods of realization of the pedagogical conditions, the list of communicative skills that students acquire in the process of learning and methods of mastering them are revealed. Attention is drawn to three pedagogical conditions: "Diplomatic informational content of educational and professional training of future specialists in international economic relations", "Personally oriented pedagogical interaction of a teacher with students" and "Communicative orientation of the content of the educational process of students in international economic relations in the process of preparing for professional diplomatic communication", with the help of which the researcher formed a professional diplomatic communication among students. All pedagogical conditions were used comprehensively. The research describes the work with students through a special training developed by the author, which includes the work on vocational oriented texts, the practice in public speaking, the creation of smart maps of visualization, the work in subgroups and so on. Attention is drawn to the culture of appealing to different officials at the beginning of communication in each individual state. The ways of independent processing of additional material about the peculiarities of diplomatic speech etiquette are revealed. The methods and techniques of the work with students, aimed at forming their needs for self-learning, self-development and self-improvement are presented.

Key words: pedagogical interaction, communicative interaction, speech etiquette, monologue, dialogue, business communication, diplomatic protocol, diplomatic etiquette, diplomatic information, group work, ethno-thinking.
\end{abstract}

у статті представлено матеріали фрормувального експерименту наукового дослі- дження на репродуктивно-діяльнісному етапі. Модель фрормування профресійнодипломатичного спілкування майбутніх фрахівців із міжнародних економічних відносин спрямована на фрормування досліджуваного конструкту в студентів, котрі навчаються за другим освітнім рівнем «Магістр». Розкрито фрорми і методи реалізації педагогічних умов, перелік комунікативних умінь, що набувають студенти у процесі навчання та методи і прийоми опанування ними. Звертається увага на три педагогічні умови: «Дипломатична інфоормативність освітньо-професійної підготовки майбутніх фрахівців з міжнародних економічних відносин», «Особистісно-зорієнтована педагогічна взаємодія викладача зі студентами» та «Комунікативна спрямованість змісту навчального процесу студентів із міжнародних економічних відносин у процесі підготовки до профессійно-дипломатичного спілкування», за допомогою яких дослідниия формувала у студентів профресійно-дипломатичне спілкування. Усі педагогічні умови використовувалися комплексно. Описується робота зі студентами за допомогою розробленого автором спеціального курсу, що передбачав роботу над профессійно-зорієнтованими текстами, вправляння в ораторському мистецтві, створення інтелектуальних карт візуалізації, роботу за підгрупами тощо. Звертається увага на культуру звертань до різних посадових осіб на початку спілкування в кожній окремій державі. Розкрито шляхи самостійного опрацювання додаткового матеріалу про своєрідність мовленнєвого етикету дипломатів. Представлено методи та прийоми роботи зі студентами, спрямовані на формування в них потреби до самоосвіти, саморозвитку, самовдосконалення.

Ключові слова: педагогічна взаємодія, комунікативна взаємодія, мовленнєвий етикет, монолог, діалог, ділове спілкування, дипломатичний протокол, дипломатичний етикет, дипломатична інсрормативність, групова робота, етномислення.
Of Mykolayiv National University

Named after V.O. Sukhomlynsky
Analysis of recent research and publications. The problems of modern national diplomacy were researched by the following national and foreign scientists: N. Hruschynskaya, B. Humeniuk, Guy Carron de la Carrier, N. Machiavelli, G. Nicholson, V. Popov and others. However, work on the professional-diplomatic communication of future specialists in international economic relations, in particular the creation and implementation of pedagogical conditions for its formation, remained understudied.

The determination of the theoretical issues of the pedagogical research (pedagogical conditions of the development of professional and diplomatic 
communication of future specialists in international political economy, the principles of constructing of the experimental methodology) made the development of an experimental model of the activating the professional and diplomatic communication of future specialists in international political economy at the second educational level «Master». The experimental model covered four interrelated stages: informationenrichment, reproductive-activity, analytically-productive, and reflective-evaluative.

The methodology of the development of professional and diplomatic communication of future specialists in international political economy (the specialty 292 «International Political Economy») was designed for the period of students studying during the first year of Master's program in IPE at the educational level «Master», and the field 29 «International Policy Studies» of the educational program «International Economics».

The aim of the paper is to disclose the implementation of the pedagogical conditions at the second stage of the developing experiment from the problem of forming professional diplomatic communication of future specialists in international economic relations.

Outline of the main research material. Let us describe the work with students at the reproductiveactive stage of the developing experiment in details. Its goal was to develop communication skills in the organization and work mechanism of multilateral and bilateral diplomatic activity, the immersion of graduate students in active communicative interaction regards to the suggested situations in diplomatic activity and the development of speech etiquette using professionally oriented texts.

The techniques of the implementation of the pedagogical conditions are the following: access to such means of communication as: electronic mail (e-mail), Facebook as an auxiliary tool for interacting with diplomats and leaders of other states; issue-related tasks (speaking at the reception, proper drafting of the correspondence, etc.); monologue analysis, dialogue analysis (polylogue); cases containing situational tasks for discussion.

All three pedagogical conditions were implemented at every stage: «Diplomatic informational content of educational and professional training of future specialists in international political economy», «Personalityoriented pedagogical interaction of the teacher and students», «Communicative orientation of the content of the educational process of students in international political economy in the process of preparing for the professional and diplomatic communication».

Upon the implementation of the developing experiment, students received the following communication skills: establishing and maintaining contact between the parties, the common and independent implementation of quasi-diplomatic activities; perceptual-expressive skills: exchange of experiences and impressions in the process of joint activity; understanding of the emotional condition, reasons, attitude, individual characteristics of others; be understood by others.

To obtain these skills in the process of the developing experiment, students were offered the following: solve situations through the ability to negotiate, take into account each other's interests, coordinate actions, carry out joint planning and joint activities; show the ability to understand the interests and aspirations of other peoples (states), master means of self-expression of emotions and conditions, be expressive and convincing, master the technique of intonation to express various forms of influence (request, order, requirement, advice, wish, question), distinguish personal characteristics of the partner through communication, take into account the mutual relations of people (states), etc. Besides, during the studying process, students gained the ethical foundations of business communication and the formation of a modern business culture; business ethics in advertising; theories and practices of carrying out business negotiations - their organization and preparation, conceptual approaches to them; psychology of business communication, tactics in negotiations and argumentation techniques, conflict prevention.

It should be noted that at all stages of the developing experiment, students studied our prepared special course «Professional and diplomatic communication of future specialists in international political economy». The special course consisted of two sections. The first section is the introduction of students to the problem of professional and diplomatic communication, an introduction to the essence of the concept of «professional and diplomatic communication», the necessity and importance of communicative interaction during a diplomatic mission. The second section is aimed at introducing and mastering the practical skills of professional and diplomatic communication that provides for diplomacy protocol and diplomacy etiquette. The special course is designed for 3 credits in volume that is equal to 90 hours. Among them 30 hours were allotted for classes, 60 hours are for students' independent work. The class hours were distributed as follows: 10 hours are for lectures and 20 hours are practical classes.

At the reproductive-activity stage, the following forms of work with students were used: lectures and practical classes of a special course, practical classes on the course «Trade Policy and Commercial Diplomacy». Besides, students performed the independent work during and outside practical classes, using such means of communication as electronic mail (e-mail), Facebook as an auxiliary tool for interacting with diplomats and leaders of other states. During the practical classes, students received issue-related tasks (speaking at a reception, proper drafting of the correspondence, etc.) submitted through the discussions in subgroups for analysis, or presented for defense as 
a homework; monologue analysis, dialogue analysis (polylogue); cases containing situational tasks for discussion, smart cards of visualization. The pedagogical conditions for the developing of the professional and diplomatic communication of future specialists in international political economy at this stage were also used comprehensively. The diplomatic informational content of the educational and professional training of future specialists in international political economy is occurred during lectures and practical classes as well as during the fulfillment of students' independent work assignments. The personality-oriented pedagogical interaction of the teacher and students was realized primarily when she / he defined individual tasks for independent fulfillment and when assigning students to subgroups for carrying out role-playing games. The communicative orientation of the content of the educational process of students in international political economy in the process of preparing for professional and diplomatic communication was embodied in tasks related to monologue, dialogue or polylogue, which were carried out under the supervision of a teacher.

At the lectures and practical classes, the students' knowledge and skills were developed to build communication during interaction in future professional and diplomatic activities, choosing the appropriate communication style, appropriate vocabulary, and choosing the right language and non-verbal means of communication. Thus, working with students, we relied on the opinion of $O$. Leontiev that the language acquisition «is primarily characterized by the choice. It means that individuals, groups of individuals, and entire generations assimilate in the language that way and as much as it corresponds to their needs in understanding the needs of any activity» [3].

The enrichment of knowledge on the construction of professionally oriented texts for diplomatic communication at lectures provided students with perfect and negative (incorrect) texts, expressive lexical means of language and speech, with methods of constructing of certain syntactic structures that allows a diplomat to negotiate at different levels of international political economy. During practical classes students reinforced the ability to work with text. Thus, after listening to the lecture material, students received their home assignment to select the texts of speeches by diplomats on economic issues on Facebook for analysis in practical classes. Working with students during practical classes on a professional text, the teacher used the following methods: discussion (text discussion or text analysis or analysis of elements and parts of the text), analysis and observation of linguistic phenomena, work with a textbook, dictionary, method of educational exercises [6] (students were suggested to repeat certain phrases with different intonations, determining its meaning in a particular case). After analyzing the correct text, students were asked to take a seat behind the podium and read it clearly, practicing in oratory. Other students evaluated the construction of monologue speech by the speaker, the ability to use expressive vocabulary, professional terminology, and analyzed the presence or absence of professional slangy words and jargonisms in the text. During the performance of such tasks, the condition of the personality-oriented pedagogical interaction of the teacher and students was realized. Students came to the conclusion that only a correctly constructed text of a diplomat's speech can lead him to success, to the desire of the opposite side to communicate with him during bilateral/multilateral negotiations. Thus, every diplomat must master the art of communication, flexibility of expression, focusing on the national characteristics of the state of communication. At the same time, it is important to send message to students that there is no single approach to develop professional and diplomatic communication, since it depends on the experience of diplomatic activity, the level of professional knowledge, oratory, knowledge of diplomatic ethics and the diplomacy protocol, the level of professional terminology and the ability to work on his professional skill.

Using the method of exercises at the second stage of the experiment in practical classes, one of the forms of the group work was suggested students to develop a smart map $[1 ; 2 ; 4 ; 5]$. Let us dwell on the development of smart cards «Form of Address according to Diplomacy Protocol» of a future diplomat of international political economy and «Courtesy Title» and the requirements for the use of addresses in diplomatic communication in details.

The goal of the task was to systematize students' knowledge of the national culture and features of such states as the USA, Austria, England, Germany, Russia, Ukraine, France and knowledge of the diplomacy protocol regards to the rules for contacting various officials at the beginning of communication in each individual state; help use their knowledge during the professional and diplomatic communication. Each map of visualization is represented in the form of a table (see Table 1 and Table 2).

It is known that different peoples do not reflect the world in the same way, which affects the specifications of linguistic means and is embodied in the originality of the national-linguistic picture of the world. That is why students were invited to familiarize themselves with the folklore works of different nations in order to reflect and preserve the traditions of the culture of speech more clearly, the way that any people during the diplomatic mission fulfill themselves, to master various forms of address to noble persons according to the traditions that exist in each particular country. Table 2 represents a pattern of the smart map of visualization «Courtesy Title».

Each map of visualization was created in a separate practical lesson. Students work on maps of 
Smart Map of Visualization "Form of Address according to Diplomacy Protocol"

Table 1

\begin{tabular}{|l|l|}
\hline \multicolumn{1}{|c|}{ Position, title } & \multicolumn{1}{|c|}{ Style of Address (Rhetorical Move) } \\
\hline Head of State & "Your Highness" \\
\hline Prince, Princess & "Your Royal Highness" \\
\hline Ministers, Ambassadors & "Honourable Minister" or "Honourable Ambassador" \\
\hline Ambassadresses & "Mistress Ambassadress" \\
\hline Extraordinary and Authorized Ambassador & "Your High Excellency!" \\
\hline Pontiff and Patriarch & "Your Holiness!" \\
\hline Metropolitan & "Your Grace!" \\
\hline Cardinal & "Your Reverence!" \\
\hline Bishop & "My Lord!" \\
\hline Eparch of Ukrainian Greek & "Your Eminence" (lat. eminentia - eminence, excellence), or "Your Excel- \\
Catholic Church & lence!" (lat. excelentia - excellence, superiority) \\
\hline Clergyman & "Father"; "Father Master / Doctor!" (if he has a scientific degree; and "Father \\
Professor!" (if he has academic honors)
\end{tabular}

Smart Map of Visualization "Courtesy title"

\begin{tabular}{|c|c|}
\hline Country, Profession, Title & Form of Address \\
\hline Austria (a representative of any art profession) & "Herr Docto" \\
\hline Germany (a representative of any art profession) & "Herr Doctor Hetmann" \\
\hline USA, England (a teacher) & "Professor" \\
\hline France (all teachers and school teachers) & "Professor" \\
\hline Austria (a wife of the Professor) & "Frau Professor" \\
\hline In west European countries & $\begin{array}{l}\text { "Mister", "Miss", "Missis" (the surname is a must after any form } \\
\text { of address) }\end{array}$ \\
\hline $\begin{array}{l}\text { Great Britain (titles of nobility - Peers (Lords } \\
\text { daughters of Dukes, Marquess and Earls }\end{array}$ & $\begin{array}{l}\text { to a man - "Peer"; } \\
\text { to a woman - "Peeress" (with adding first name in the beginning); } \\
\text { "Lady". }\end{array}$ \\
\hline $\begin{array}{l}\text { Great Britain and France (Courtesy Title) } \\
\text { younger sons of Dukes and Marquesses; } \\
\text { younger sons of Dukes, Earls and all sons of Viscounts } \\
\text { and Barons; } \\
\text { parental title of nobility "Baronet" (intermediate between } \\
\text { minor ranks of nobility and middle ones), short. "Bart"; } \\
\text { a wife of Baronet; } \\
\text { Baronetess (received as her own award) }\end{array}$ & $\begin{array}{l}\text { Duke, (Marquess, Earl and Viscount is used only in official } \\
\text { meetings. In other situation "Lord", "Lady" or "Baron" is used; } \\
\text { Lord; } \\
\text { "High and Potent Lord" } \\
\text { "Sir" + first name } \\
\text { "Lady" + surname of the husband; } \\
\text { "Madam" (Dame) }\end{array}$ \\
\hline France - Duke or Duchess & "Duke" and "Duchess" \\
\hline $\begin{array}{l}\text { Domestic judicial system: } \\
\text { addressing of Judges to the Presiding Judge in the } \\
\text { hearing of Constitutional Court of Ukraine; } \\
\text { addressing to the participants of judicial system. }\end{array}$ & $\begin{array}{l}\text { "High Court", "Your Honor", "Honourable Presiding Judge", } \\
\text { "Honourable Judge”; } \\
\text { "Dear Party", "Dear Party's Representative", "Dear Witness", } \\
\text { "Dear Expert" and others. }\end{array}$ \\
\hline
\end{tabular}

visualization as follows. The teacher divided the students group into 2-3 subgroups in an authoritarian way, creating subgroups that are equal in the level of knowledge. The students of each subgroup seemed to have a card with filling in the left column and a set of strips with the wording of various form of address. On the right side of the map, it was necessary to lay out strips with the right address to the titled persons or people of a certain profession in the corresponding country. Upon the completion of work in each subgroup, students on the board along with the teacher filled out a map of visualization. The team received 5 points for each correct answer. The team that scored the most points won.

A significant place in experimental research training during the second stage of the developing experiment was given to interactive methods, in particular, such as working in pairs, working in groups, a microphone, and others, which promoted to creating comfortable learning conditions for each student under which he felt his success, intellectual solvency. Interactive methods prompted future specialists in 
international political economy to communicate, think critically, and make careful decisions. Thus, after creating a smart card, the teacher invited students to listen to some short welcome speeches by top officials of the host party and the guest's speech in response to official visits to protocol events (receptions, lunches, breakfasts), which are essentially a continuation of negotiations, followed by the discussion with students of forms of address.

By preparing students for the topic «Peculiarities of the speech etiquette of diplomats», they could independently develop additional material on the peculiarities of the speech etiquette of diplomats. During the practical lesson, students delivered a message prepared by each subgroup in advance.

Message 1. «Traditional forms of addresses of Ukrainians».

Message 2. «Bilateral verbal note on economic problems».

Message 3. «Letter of Minister of Foreign Affairs».

Message 4. «Memorandum of investment administrations».

At this stage of the study, we focused on the development of students' needs for self-education, selfdevelopment, and self-improvement. After listening to each message, according to the materials, students of other subgroups were assigned tasks related to the type of message, such as:

- Describe the presentation of the memorandum.

- Choose the options of existing courtesy formulas for preparing a diplomatic note, giving it a strict dry tone or great warmth.

- Name the forms of beginning and completion of the text of personal correspondence and the use of compliments, taking into account the political, official position or rank of the proper person with whom correspondence is being carried on.

Therefore, this stage of the experimental work was aimed at the practical implementation of the knowledge acquired by students in practical classes in the special course. A number of discussions («Multilateral Modern Economic Diplomacy: Forms of Negotiations», «Professional and Diplomatic Communication as a Path to Successful Negotiations»), competitions («Whose Team is Faster», «The Best Speaker»); self- education of students on the topics: «Online System in Training», «Documents of International Diplomatic Practice»; work in the circle «Creative Laboratory of the Diplomat» were held. The development of professional and diplomatic communication skills took place during the study of the professionally oriented disciplines: «Trade Policy and Commercial Diplomacy» and «Ukrainian Business Speech».

Conclusions. Work with students carried out at the reproductive-activity stage, made it possible to prepare for the next, analytically-productive stage, aimed at developing the culture of speech of future diplomats and its expressiveness. Thus, the integrated use of the pedagogical conditions promotes to a more effective training of students for professional and diplomatic communication..

\section{REFERENCES:}

1. Budd, J. W. (2004). Mind Maps as Classroom Exercises. Journal of Economic Education. Vol. 35. № 1. P. 35-49.

2. Buzan, T., Buzan, B. (1994). The mind map book: How to use radiant thinking to maximize your brains untapped potential. Dutton.

3. Leontiev A.A. (1969) Yazyk, rech, rechevaia deiatelnost [Language, speech and oral activity]. Moscow [in Russian].

4. Mento, A.J., Martinelli, P., Jones R.M. (1999). Mind Mapping in Executive Education: Applications and Outcomes. The Journal of Management Development. Vol. 18, Issue 4.

5. Paderno V.V. (2017). Formuvannia profesiinoyi identichnisti v maibutnikh uchyteliv humanitarnykh dystsyplin [The formation of professional identity in future teachers of the humanities]. Candidate's thesis. Odesa [in Ukrainian].

6. Chernykh I.O. Profesiyno oriientovanyi tekst iak zasib zbahachennia slovnykovoho zapasu studentiv - maibutnikh likariv [Professionally oriented text as a means of enriching the vocabulary of students - future doctors]. URL: http://www.ps.stateuniversity.ks.ua/file/ issue_42/89.pdf [in Ukrainian].

7. Sharov, O. (2012). Shchodo shliakhiv vdoskonalennia orhanizatsii roboty $v$ haluzi ekonomichnoi dyplomatii: stratehichni aspekty. Analitychna zapyska. [On the ways of improving work in the sphere of economical diplomacy: strategic aspects. Analytical notes]. URL: http://www.niss.gov.ua/articles/975/ [in Ukrainian]. 